\title{
Insecticidal activity of selected botanicals on maize weevil, Sitophilus zeamais L., in stored maize grains
}

\section{S. Karunakaran ${ }^{1}$ and V. Arulnandhy ${ }^{2}$}

${ }^{1}$ Staff, Faculty of Agriculture, Eastern University, Sri Lanka.

2Retired Professor, Eastern University, Sri Lanka.

\begin{abstract}
Laboratory studies were conducted to find the effect of powdered leaf of five plant species such as lantanas or shrub verbenas (Lantana camera), neem (Azadiracta indicia), annona (Annona squamosa), Adathodai (Justicia adhatoda) and Tulsi (Ocimum tenuiflorum) along with chemical pesticide Actellic $5 E C(500 \mathrm{~g} / \mathrm{l}$ pirimphos-methyl) against maize weevil, Sitophilus zeamais L., infesting maize grains in storage. Among them Ocimum tenuiflorum (Tulsi) was found to be significantly the best compared to other treatments. It was registered that Ocimum tenuiflorum (Tulsi) and Annona squamosa (Annona) killed 86 percentage of adult weevils by about 6th week. Furthermore, the damage was completely controlled in the grains treated with Ocimum tenuiflorum after eight weeks and almost same in grains applied with Annona squamosa. In addition, significant differences were found between the numbers of emerged weevils in different treatments. In the grains treated with Actellic, Ocimum tenuiflorum and Annona squamosa, the new emerged weevils were not observed and the appearance of newly emergrd weevils were observed in Lantana camera, Azadiracta indica and Justicia adhatoda from 6th week and it was higher in Lantana camera compared to the Azadiracta indica and Justicia adhatoda from 6th week onwards.
\end{abstract}

Keywords: Sitophilus zeamais L, Azadiracta indica, Annona squamosa, Justicia adhatota ,Ocimum tenuiflorum, Actellic

\section{Introduction}

Maize is the most important cereal crop in the world after wheat and rice. It is used for mainly three purposes, as a staple human food, as feed livestock and as a raw material for many industrial products (Purseglove, 1975). In developing countries, maize production and consumption often falls below demand as a result of post-harvest losses due to storage pests and other spoilage agents (Udo, 2005). This results in major economic losses and threatens food security (Ivbijaro et al. 1979). The problem is mostly severe in developing countries in the tropics due to unfavorable storage conditions and poor storage structures (Bekele et al. 1997). In Sri Lanka, maize is not usually available throughout the year, hence it has to be stored for its continuous availability. High

Corresponding author: selvikaruna23311@yahoo.com Received: 18.04.2017 moisture predisposes grain to attack by bacteria, fungi, insects and other microbes (Golob, 2000). However, in storing maize, the problem of pest infestation, especially that the insect Sitophilus zeamais is one of the major damaging store pests of economic importance in stored maize. It is so devastating and is capable of multiplying to large populations causing tremendous damage to the grain. It belongs to the order Coleoptera and family Curculionidae, and is a tiny weevil measuring 3 to $3.5 \mathrm{~mm}$ long with dull brown colour (Hill, 1987). It can live for a period of up to 12 months, depending on environmental conditions (Longstaff, 1981). Initial infestation of maize by the adult weevil occurs in the field and continues during storage (Adedire \&

https://orcid.org/0000-0002-0671-267X

Accepted: 29.01.2018 
Lajide, 2003). To ensure high food quality and safety standards, which are acceptable to consumer quality control, including good storage and handling practices must be observed at all times (Kenny, 1998). Synthetic chemical (e.g. Actellic) can be used to control this storage pest in an efficient way. However, these insecticides are expensive and out of reach to the poor farmers (Murdock and Kitch, 1997). Thus led to insect resurgence and also has a negative effect on non-target organisms,so this demands for cheaper alternatives (Duke et al., 2003).

Plant materials with insecticidal properties provide an opportunity for small scale farmers instead of chemicals that are locally and readily available, affordable, relatively its nonpoisonous to human health and less detrimental to the environment for pest control (Talukder \& Howse, 1995). However, very little research has been performed on the development of affordable organic pesticides which offer same control levels as synthetics to weevils (Cosmas et al., 2012). Hence, this present research aimed to examine the effect of five locally available botanicals on survival, mortality, rate of damage and emergence of Sitophilus zeamais in stored maize grains.

\section{Material and Methods}

The investigation was conducted in the Department of Agric.Biology, Eastern University, Sri Lanka, Vantahrumoolai from November 2013 to March 2014. Two hundred and fifty grams of fresh matured leaves of shrub verbenas (Lantana camera), neem (Azadiracta indicia), annona (Annona squamosa), Adathodai (Justicia adhatoda) and Tulsi (Ocimum tenuiflorum) were collected from vantharumoolai area and dried under shade until the leaves become crispy. The dried leaves of each species were ground using a domestic electric grinder separately to a fine powder and sieved through a mesh sieve $(0.1 \mathrm{~mm}$ pore size) to obtain uniform particular size. The resulting powders were labeled and kept separately in glass containers with screw cap and stored at room temperature in a dark place until used in the investigation. Adult insects of the maize weevil, Sitophilus zeamais was obtained from already infested maize grains from the agricultural biology laboratory cultures. Adult weevils were introduced into three insect jars (lxwxh-15cm $\times 15 \mathrm{~cm} \times 20 \mathrm{~cm})$ containing $500 \mathrm{gm}$ of un-infested maize grains in each jars for mass rearing. These jars were covered with thin netting held in place by rubber bands to prevent the weevils from getting out and the emerging weevils were used for experiment.

Cleaned and well sieved maize grains obtained from Agronomy farm, Eastern University, Sri Lanka immediately after harvesting were used in this experiment. Seeds were frozen at $-60 \mathrm{C}$ in the deep freezer for 07 days to kill any live insects on and in it as stated by G.Fekadu et al 2012. Afterwards, $100 \mathrm{~g}$ of maize grains were put into separate $14 \mathrm{~cm} \times 9 \mathrm{~cm} \times 4 \mathrm{~cm}(1 \times \mathrm{w} \times \mathrm{h})$ capacity polymate plastic boxes covered by cardboard cover with tiny holes. Five pairs of male and female insects were introduced to the above maize grains and $10 \mathrm{~g}$ of botanicals were added and set out in a complete randomized design (Fig. I). The sexes of $\mathrm{S}$. zeamais were determined by examining characterstics of the snout. The snout of females are longer and thinner while that of the males are shorter and fatter. In addition, the females have smooth textured bodies while that of males are rough (Kranz et al, 1978).

Five replications were included for each treatment. The botanical treatments were compared regularly at two weeks interval with the control (untreated) and surface treatment of chemical Actellic at recommended rate of $3.0 \mathrm{fl} \mathrm{oz}$ per 2 gallons of water per 1,000 square feet (Wanye C. Bailey 2011) on number of live weevils, mortality of weevils, number of damaged maize grains and new adult emergence were collected preciously. 


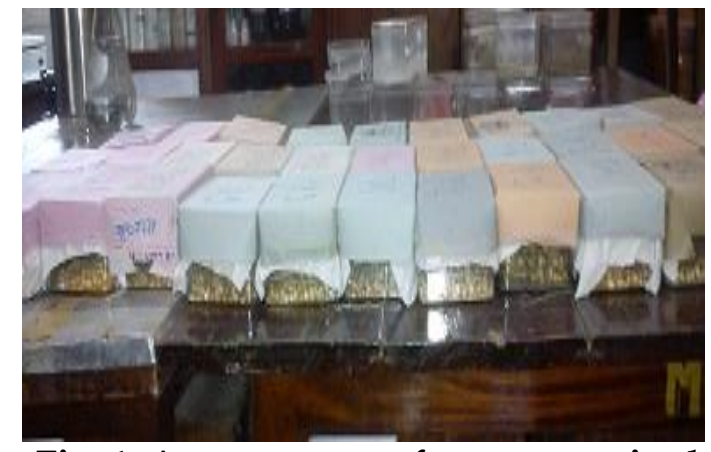

Fig. 1. Arrangement of treatments in the experiment

The collected data were subjected to ANOVA and the means of different treatments on various parameters were compared using DMRT

\section{Results And Discussion}

\section{Survival and mortality of adult weevils}

Ten weevils ( 5 males and 5 females in pairs) were introduced into each box to see the effect of treatments botanical pesticide and chemical pesticide Actellic used as chemical checked on the survival and mortality of weevils as compared to untreated control (Fig.2) and the observations were made at fortnight intervals and the mean values of the survival at fortnight were calculated. The chemical pesticide Actellic showed the best control of weevils from the beginning as at 2 weeks of treatment followed by Ocimum tenuiflorum (Tulsi) and Annona squamosa (Annona). All weevils were killed by the $4^{\text {th }}$ week in Actellic treatment meanwhile Ocimum tenuiflorum (Tulsi) and Annona squamosa (Annona) destroyed almost all weevils by about the $6^{\text {th }}$ week of treatment indicating significantly more effective than all botanical and control included in this investigation. It was found that these two botanicals killed 86 percentage of adult weevils by about $6^{\text {th }}$ week and the chemical Actellic killed 90 percent of the adult weevils by about the $2^{\text {nd }}$ week after treatment and no weevils were found alive from $4^{\text {th }}$ weeks onwards.

Hence, Ocimum tenuiflorum (Tulsi) and Annona squamosa (Annona) have the highest potential to control of Sitophilus zeamais weevils among the botanicals tested and are comparable to chemical insecticide "Actellic".

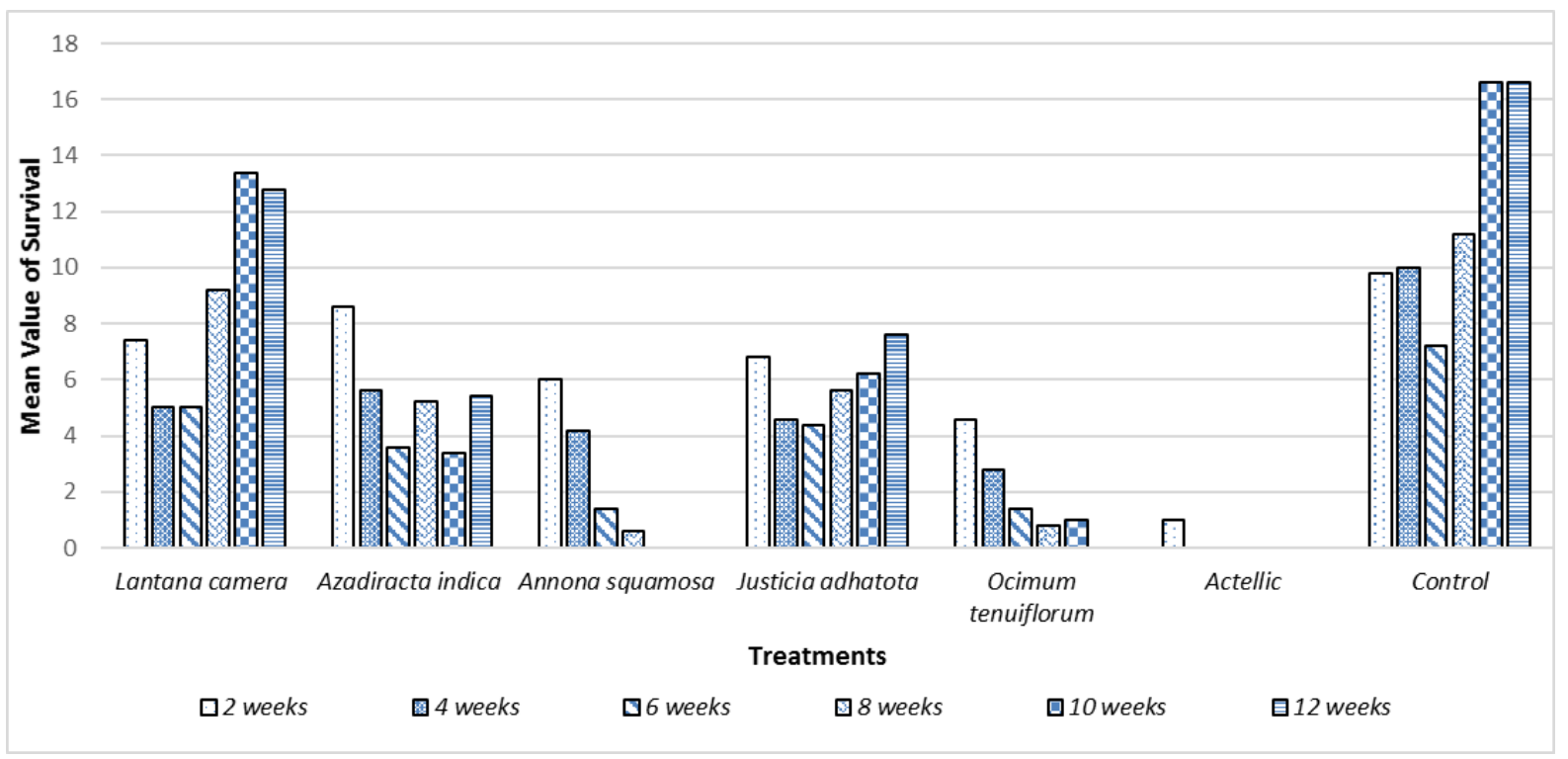

Fig. 2. Effect of botanicals and Actellic on the survival of adult weevils 
The rate of killing by different botanicals may be attributed to the toxic nature of them. The efficient control of storage pest has been reported earlier that insecticidal action of five plant species against maize weevil, Sitophilus zeamaiz by Maribet et al, (2008) in Philippines. The researchers reported that same pest was control by the botanicals such as Azadiracta indicia, Cymbopogon citrates, Lantana camara, Ocimum basilicum and Tagetes erecta. In addition, the use of their leaf extract is also recommended as insecticide against maize weevil.

\section{Number of grains damaged by the maize weevil}

When consider the damaged grains, only larval tunnels were observed in all corn grains examined. Deposition of eggs was not observed on the grains.
Results from Table 1 shows that the control had the highest number of damaged maize grains throughout the research period and it was followed by the Lantana Camera and Azadiracta indica powder. The damage was not visible in the grains treated with chemical pesticide and it was completely controlled in the grains treated with Ocimum tenuiflorum after eight weeks and almost same in grains applied with Annona squamosa (Annona).

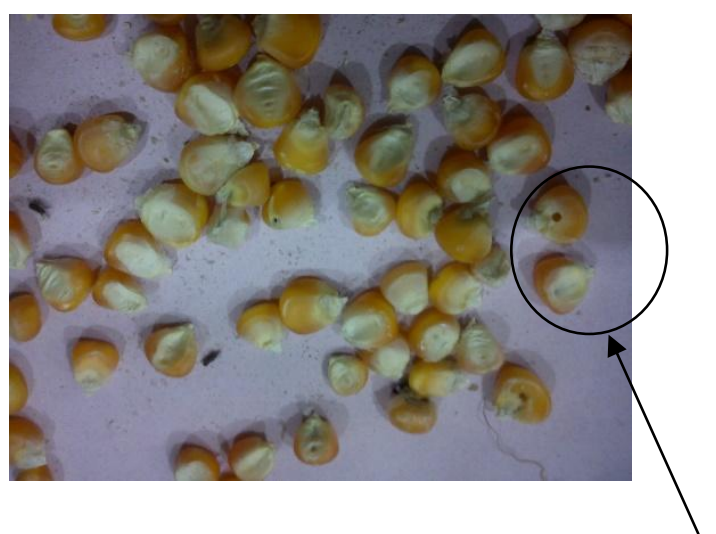

Fig. 3. Damaged grains Damaged grain

Table 1. Effect of botanicals on the number of damaged grains

\begin{tabular}{|l|l|l|l|l|l|l|}
\hline \multirow{2}{*}{ Treatment } & \multicolumn{7}{c|}{ Damage grains } \\
\cline { 2 - 8 } & $\begin{array}{l}2^{\text {nd }} \\
\text { week }\end{array}$ & $\begin{array}{l}4^{\text {th }} \\
\text { week }\end{array}$ & $\begin{array}{l}6^{\text {th }} \\
\text { week }\end{array}$ & $\begin{array}{l}8^{\text {th }} \\
\text { week }\end{array}$ & $\begin{array}{l}10^{\text {th }} \\
\text { week }\end{array}$ & $\begin{array}{l}12^{\text {th }} \\
\text { week }\end{array}$ \\
\hline Lantana camera & $1.2 \mathrm{ab}+$ & $4.2 \mathrm{~b}$ & $8.2 \mathrm{a}$ & $13.6 \mathrm{a}$ & $19.2 \mathrm{~b}$ & $15.2 \mathrm{~b}$ \\
\hline Azadiracta indica (Neem) & $0.8 \mathrm{ab}$ & $3.4 \mathrm{~b}$ & $2.4 \mathrm{~b}$ & $10.2 \mathrm{~b}$ & $10.4 \mathrm{c}$ & $10.4 \mathrm{c}$ \\
\hline Annona squamosa (Annona) & $1.8 \mathrm{a}$ & $2.4 \mathrm{~b}$ & $2.0 \mathrm{~b}$ & $2.4 \mathrm{c}$ & $0.2 \mathrm{~d}$ & $0.2 \mathrm{~d}$ \\
\hline Justicia adhatota (Adathodai) & $0.4 \mathrm{ab}$ & $3.6 \mathrm{~b}$ & $7.4 \mathrm{a}$ & $10.0 \mathrm{~b}$ & $10.0 \mathrm{c}$ & $7.4 \mathrm{c}$ \\
\hline Ocimum tenuiflorum (Tulsi) & $1.4 \mathrm{ab}$ & $2.6 \mathrm{~b}$ & $2.8 \mathrm{~b}$ & $2.8 \mathrm{c}$ & $0.0 \mathrm{~d}$ & $0.0 \mathrm{~d}$ \\
\hline Actellic 5EC (500g/l pirimphos-methyl) & $0.0 \mathrm{~b}$ & $0.0 \mathrm{c}$ & $0.0 \mathrm{~b}$ & $0.0 \mathrm{c}$ & $0.0 \mathrm{~d}$ & $0.0 \mathrm{~d}$ \\
\hline Control & $0.8 \mathrm{ab}$ & $7.2 \mathrm{a}$ & $8.8 \mathrm{a}$ & $14.4 \mathrm{a}$ & $23.8 \mathrm{a}$ & $32.2 \mathrm{a}$ \\
\hline
\end{tabular}

+Means followed by same letter in each column do not differ statistically at $\mathrm{p}<0.05$ based on DMRT

Number of adult emergence of weevils

Table 2. Efficacy of Botanicals on adult emergence

\begin{tabular}{|l|l|l|l|l|l|l|}
\hline \multirow{2}{*}{ Treatment } & \multicolumn{6}{c|}{ No.of adult emergence } \\
\cline { 2 - 7 } & $\begin{array}{l}2^{\text {nd }} \\
\text { week }\end{array}$ & $\begin{array}{l}4^{\text {th }} \\
\text { week }\end{array}$ & $\begin{array}{l}6^{\text {th }} \\
\text { week }\end{array}$ & $\begin{array}{l}8^{\text {th }} \\
\text { week }\end{array}$ & $\begin{array}{l}10^{\text {th }} \\
\text { week }\end{array}$ & $\begin{array}{l}12^{\text {th }} \\
\text { week }\end{array}$ \\
\hline Lantana camera & $0.0 \mathrm{a}^{*}$ & $0.0 \mathrm{~b}$ & $1.4 \mathrm{ab}$ & $4.8 \mathrm{a}$ & $8.8 \mathrm{~b}$ & $7.6 \mathrm{a}$ \\
\hline Azadiracta indica (Neem) & $0.0 \mathrm{a}$ & $0.0 \mathrm{~b}$ & $0.2 \mathrm{~b}$ & $0.8 \mathrm{bc}$ & $0.8 \mathrm{c}$ & $1.2 \mathrm{c}$ \\
\hline Annona squamosa (Annona) & $0.0 \mathrm{a}$ & $0.0 \mathrm{~b}$ & $0.0 \mathrm{~b}$ & $0.0 \mathrm{c}$ & $0.0 \mathrm{c}$ & $0.0 \mathrm{c}$ \\
\hline Justicia adhatota (Adathodai) & $0.0 \mathrm{a}$ & $0.0 \mathrm{~b}$ & $0.6 \mathrm{~b}$ & $0.8 \mathrm{bc}$ & $0.6 \mathrm{c}$ & $2.2 \mathrm{c}$ \\
\hline Ocimum tenuiflorum (Tulsi) & $0.0 \mathrm{a}$ & $0.0 \mathrm{~b}$ & $0.0 \mathrm{~b}$ & $0.0 \mathrm{c}$ & $0.0 \mathrm{c}$ & $0.0 \mathrm{c}$ \\
\hline Actellic 5EC (500g/1 pirimphos-methyl) & $0.0 \mathrm{a}$ & $0.0 \mathrm{~b}$ & $0.0 \mathrm{~b}$ & $0.0 \mathrm{c}$ & $0.0 \mathrm{c}$ & $0.0 \mathrm{c}$ \\
\hline Control & $0.0 \mathrm{a}$ & $0.8 \mathrm{a}$ & $2.5 \mathrm{a}$ & $5.6 \mathrm{a}$ & $9.2 \mathrm{a}$ & $14.4 \mathrm{a}$ \\
\hline
\end{tabular}

*Means followed by same letter in a column do not statistically differ $(\mathrm{p}<0.05)$, based on DMRT. 
The effect of botanicals on the population increase of S.zeamais is shown in Table 2. Significant differences were found between the numbers of emerged weevils in different treatments. When compared with the control, there was a significant reduction in emergence of weevils in grains in other treatments. In control treatment, the newly emerged was started from $4^{\text {th }}$ week (0.8) and it was increased till end of the observation (14.4). In the grains treated with Actellic, Ocimum tenuiflorum and Annona squamosa, the new births were not visible and the appearance of emergence of new weevils were observed in Lantana camera, Azadiracta indica and Justicia adhatota from $6^{\text {th }}$ week and it was high in Lantana camera compared to the Azadiracta indica and Justicia adhatota from $6^{\text {th }}$ week onwards.

\section{Conclusions}

The results revealed that the tested botanicals are effective in killing weevils and few of them suppress the emergence of new weevils. The efficacy of ground Ocimum tenuiflorum was the highest among the botanicals and followed by Annona squeamish. These two botanicals suppress the emergence of new weevils as well. Therefore, the resource poor farmers can use ground botanical Ocimum tenuiflorum in controlling maize weevils. Additional advantages are Ocimum tenuiflorum is grown widely under our climatic conditions and its non-poisonous nature to human when use as insecticide in stored maize grains.

\section{References}

Adedire, C.O. \& Lajide, L. (2003). Ability of extracts of ten tropical plant species to protect maize grains against infestation by the maize weevil, Sitophilus zeamais, during storage. Nigeria Journal of Experimental Biology, 4, 175-179.

Bekele, A. J., Obeng-Ofori, D. \& Hassanali, A. (1997). Evaluation of Ocimum kenyense (Ayobangira) as source of repellants, toxicants and protectants in storage against three major stored product insect pests. Journal of Applied Entomology, 121, 169 - 173.

Cosmas, P., Christopher, G., Charles, K., Friday, K., Ronald, M. and Belta, Z. 2012. Tagetes Minuta Formulation Effect Sitophilus zeamais (Weevils) Control in Stored Maize Grain. International Journal of Plant Research. 2(3): 65-68.

Duke.S.O, Baemson .S. R and Dayan. A. M. (2003) Research on natural products for pest management, US department of agriculture, Agriculture Research Services, Sci Sa, 708-717.

Fekadu, G., Waktole, S. and Dante R Santiago (2012). Evaluation of plant powders and cooking oils against Maize Weevil Sitophilus zeamais M. (Coleopteran: Curculionidae) under Laboratory Conditions.

Golob. P. (2000). A practical assessment of food losses sustained during storage by smallholder farmers in the Shire Valley Agriculture Development area of Malawi, Department of the Tropical Products Institute, Slough G 138 p 32

Hill, S. D. (1987). Agricultural Insect Pests of the Tropics and their Control. (2nd edi.). London: Cambridge University Press, 492 pp.

Ivibijaro, M. F., Osisanya, E. O. and Akinlade, E. E. (1979). The deterioration of commercial maize by insects and fungi. International Biodeterioration Bulletin, 15, 74 76.

Kranz, J., Schmutterer, H. and Koch, W. (1978). Disease, pests and weeds in tropical crops, Great Britain: John Wiley and Sons Limited, 564pp.

Longstaff, B, C. (1981). Biology of the grain pest species of the genus Sitophilus: (Colieoptera: Curculionidae): A critical review. Protection Ecology, 2, 83-130. 
Maribet, L., Parugrug and Aurea, C. Roxas (2008). Insecticidal action of five plants against maize weevil, Sitophilus zeamais Motsch. (Coleoptera: Curculionidae), Department of Crop Production / Research Office, Central Luzon State University, Science City of Munoz, Nueva Ecija, Philippines, KMITL Sci, Tech. J. Vol. 8 No 1 Jan. 2008.

Murdock, L. L. and Kitch, C. (1997) Postharvest storage of cowpeas in Sub- Saharan Africa, Bulletin of Entomological Research 52,635-645.

Purseglove, J.W. (1975) Tropical crops:Monocotyledons. USA: Longman Group Limited, 551 pp.

Talukder, F.A. and Howse, P.E. (1995). Evaluation of Aphanamaxis polystachya as a source of repellents, antifeedants, toxicants and protectants in storage against Tribolium castaneum (Herbst). Journal of Stored Product Research, 31, 55 - 61.

Udo, I. O. (2005). Evaluation of the potential of some local spices as stored grain protectants against the maize weevil, Sitophilus zeamais Motsch (Coleoptera: Curculionidae). Journal of Applied Sciences and Environmental Management, 9(1), 165 168.

Wright M.A.P. (1995). Loss assessment for stored products in the Tropics: Appropriateness Understanding.

Wayne C.Beiley. (20011). Integrated Crop and Pest Managemet News Article, Intergrated Pest Management University of Missouri, USA. 